Fedulova Iryna,

D.Sc. (Economics), Professor, Kyiv National University of Trade and Economics,

Kiyv, Ukraine

ORCID 0000-0002-8802-137X

ResearcherID B-4644-2017

Lanovska Halyna,

$\mathrm{PhD}$ in Economics, Associate Prof., Kyiv National University of Trade and Economics (Ukraine)

ORCID 0000-0001-9732-4025

Researcher ID D-2277-2017

Bagatska Kateryna,

$\mathrm{PhD}$ in Economics, Associate Prof., Kyiv National University of Trade and Economics (Ukraine)

ORCID 0000-0003-2184-2971

Researcher ID R-3813-2018

\title{
FINANCIAL SECURITY OF UKRAINE IN THE CONTEXT OF FORMING A NATIONAL BRAND OF A COMPETITIVE ECONOMY
}

Abstract. Globalization, along with its positive impact, poses significant challenges to the economic security of a country that does not have a highly developed status, whose national brand is not identified as strong and competitive in the minds of stakeholders. The categories "economic security» and «financial security» evolve over time and are characterized by the complexity and breadth of relations that arise between economic actors. The risk and inconsistency of globalization lies in the fact that highly developed TNC-based countries are gaining significant benefits from the global economy, while host countries find themselves outsiders and vulnerable to crises. Under modern conditions, the influence of the globalized financial system on a separate state also goes to a qualitatively new level. Globalization creates conditions for the establishment of a special financial authority, which, with the possession of world money and the management of value, management of financial flows can affect both the entire world economic space, and on individual states. In this regard, the issue is considered of securing Ukraine's economic security, including financial security, is an urgent priority of the country's foreign and domestic strategy and policy to increase its competitiveness through the formation of a national brand.

Keywords: economic security, financial security, risk, globalization, competitiveness, national brand. 
Федулова Ірина, Галина Лановська, Багацька Катерина. Фінансова безпека Украйни в контексті формування національного бренду конкурентоспроможної економіки.

Глобалізаиія, разом із ї̈ позитивним впливом, створює значні виклики економічній безпеці країни, яка не має статусу високорозвиненної, національний бренд якої не визначений як сильний та конкурентоспроможний у свідомості зацікавлених сторін. Категорії «економічна безпека» та «фінансова безпека» розвиваються з часом і характеризуються складністю та широтою відносин, що виникають між економічними суб'єктами. Ризик та неузгодженість глобалізаиії полягає в тому, що високорозвинені країни, що базуються на ТНК, отримують значні вигоди від світової економіки, а приймаючі краӥни відчувають себе аутсайдерами та вразливими до криз. В сучасних умовах вплив глобалізованої фінансової системи на окрему державу також виходить на якісно новий рівень. Глобалізація створює умови для створення спеціального фінансового органу, який при володінні світовими грошима та управлінням вартістю, управлінням фінансовими потоками може впливати як на весь світовий економічний простір, так і на окремі держави. У зв'язку з иии питання забезпечення економічної безпеки України, включаючи фінансову безпеку, є актуальним пріоритетом зовнішньої та внутрішньої стратегії країни та політики підвищення ї̈ конкурентоспроможності через формування національного бренду.

Ключові слова: економічна безпека, фінансова безпека, ризик, глобалізація, конкурентоспроможність, національний бренд.

Relevance of research topic. Formation of the national brand as the basis for the competitive development of Ukraine is determined by its disposition in the coordinates of the new international economic order through the implementation of the strategic tasks of achieving economic self-sufficiency, the inclusion of national economic agents in global cost chains, maximizing the use of the effects of integration into the European and North Atlantic structures in order to guarantee national economic security and political sovereignty.

However, the aspects of development the national brand in the context of investment and financial security remain insufficiently developed. This concerns, first of all, the study of paradigmatic principles for the formation of Ukraine's economic security, in particular investment and financial security in the face of globalization challenges and the desire to position the country as an investment attractive and financially stable.

Formulation of the problem. The task is set a comprehensive study of financial security in the context of the development of the Ukrainian national brand. The purpose of the study is to substantiate the need to ensure the country's financial security in the context of the formation of a new international order through the development of the national brand of Ukraine as an economically self-sufficient and 
competitive partner. The research was based on the use of methods of analysis and synthesis in identifying and characterizing the innovation-technological resource to ensure a high competitive status of the state, specifying the main directions of ensuring the investment and financial security of Ukraine in the conditions of global instability in the context of forming a strong national brand.

Analysis of recent researches and publications.S. Lekar (2014) notes that in the conditions of globalization from the standpoint of standard theoretical and economic explanations one cannot find exhaustive answers to the questions: why in the country these are exactly, and not other balance of payments, exchange rate, crisis phenomena, state budget, state debt, discount rate, prices, income, etc. It is difficult to characterize the credit granted to the state, which may be partner or exploitative, objectively necessary or subjectively fictitious, voluntary or compulsory, productive or redistributive, etc.

S. Alhont (2007) defines the formation of the country's brand as a systematic process of harmonizing the actions, behaviour, investments, innovations and communications of the country in order to implement the national security strategy and competitive identity. O. Piankova (2014) emphasizes importance of the food and beverages brand positions in the country's brand formation.

We agree with the definition of the financial security of the state, which scientists O. Baranovsky (2004), O. Pidhovniy, O. Biletskaya, I. Shevtsova (2008), O. Ivashko (2015) define as the main criterion of its ability to carry out an independent financially-economic policy in accordance with their national interests. Y. Harazishvili, E. Drony (2014) define a state of budgetary, tax and monetary systems that guarantees the state's ability to form, store against depreciation and use financial resources to provide social and economic benefits ichnology development and servicing of financial obligations.

According to O. Pidhovniy, O. Biletska, Ya. Shevtsova (2008) this security is conditioned by the ability of state bodies to ensure the sustainability of the state's development against, such as: the impact of global financial crises; deliberate actions of participants in world financial and economic relations (states, transnational corporations, etc.); the influence of shadow (clan-corporate, mafia etc.) structures on the national economic and socio-political system, the spread of crimes and administrative offences in the financial sphere, in particular, legalization (laundering) of proceeds from crime; significant leakage of capital abroad; capital outflow from the real sector of the economy; conflicts between officials of different levels regarding the distribution and use of resources of the national budget system.

According to S. Lekar (2014) the financial security of the state depends on the favorable investment climate, that is, the totality of political, legal, economic and social conditions that ensure the investment activity of domestic and foreign investors.

Presenting main material. The results of the research allowed to substantiate a comprehensive description of the systemic problems of the national financial sector of 
Ukraine. The main of them are: low level of capitalization of domestic financial institutions and staying in the structure of oligarchic financial and industrial groups, a significant proportion of problem assets in the balance sheets of banks and the unbalanced structure of their assets and liabilities, insufficient size of their own and regulatory capital of banking institutions, the steady reduction of the share of large European players in the financial sector in Ukrainian economics, a significant lack of initial public offerings of shares of Ukrainian companies on domestic and foreign exchanges etc.

The authors identify the main directions of ensuring investment and financial security in the context of the development of national brand of Ukraine, namely: formation and positioning in the minds of stakeholders of Ukraine as a stable and reliable partner through raising the level of capitalization of the banking system at the expense of mergers and acquisitions of banks; activating monetary instruments of the NBU in the realization of the discount policy; development of an effective national depository clearing system; consolidation of domestic stock market institutions; formation of a single central depository of corporate securities; strengthening of information provision of foreign investors regarding the potential of the national stock market and the formation of its positive image; increasing the requirements for corporate governance, etc.

V. Mykhaylyuk (2014), A. Poruchnyk (2008) are represented external threats to the financial and investment security of the country, which are caused by the following factors:

- rapid processes of internationalization and globalization of the world economy;

- limited access to foreign financial markets;

- a variety of financial instruments and a high level of their dynamic;

- excessive dependence of national economies on international loans;

- increased competition between states, the use of strategies of «conquest» by powerful states in relation to less developed countries of the world;

- the emergence of threatening crisis trends in the world financial system, the inability of international financial institutions and supranational organizations to control and prevent them;

- high level of dollarization of the national economy;

- threat of excessive accumulation of foreign assets and liabilities of the country;

- increase in the scale of the shadow outflow of national capital abroad.

Studying the works of scientists has led to the conclusion that the most urgent component of both financial security in the current conditions of financial globalization is debt security; which directly affects the investment attractiveness of the recipient and the strength of the national brand. 
According to Picture 1 starting from 2014, the level of debt security - the ratio of state and guaranteed public debt to GDP exceeded the $70 \%$ barrier and in subsequent years continued to grow gradually till 2016 year. Decreasing this ratio after 2016 indicates a gradual increase in state's financial security.

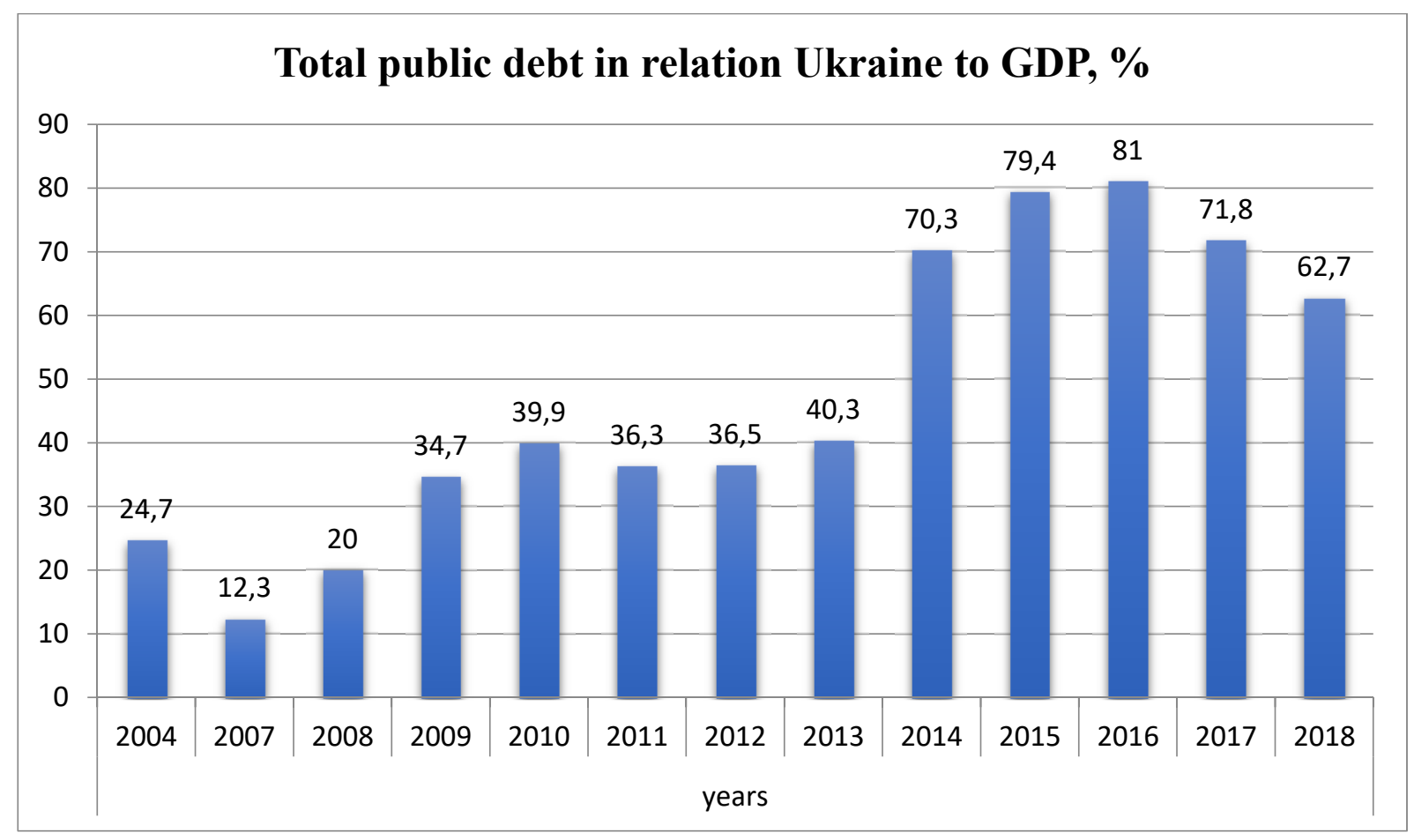

Picture 1. Dynamics of Ukraine's total public debt as a percentage of GDP

Source: Accounting Chamber, 2004-2018; Progress report and results of implementation of the program of activities of the Cabinet of Ministers of Ukraine, 2018, NRA «RURIC», 2015-2017; National Bank of Ukraine, 2004-2018); State Statistics Service of Ukraine, 2004-2018.

At the same time, the experts IMF Y. Subbotovich, O. Antropova (2013) of the grounded the threshold of external debt for low and middle income countries at the level of $49.7 \%$ of GDP. This situation has caused a significant drop in Ukraine's credit rating and, consequently, a significant reduction in the inflow of foreign investment. A great challenge to the country's debt security was the tendency to increase the share of debt denominated in foreign currency, which at the end of 2015 amounted to $41,6 \%$. However, during the following years, the share of external debt in GDP began to gradually decline, indicating a slow increase in the level of debt security (Picture 2). In general, state and state-guaranteed debt of Ukraine in 2014-2018 exceeded the critical level $(60 \%)$ of the relevant debt indicator set by the criteria of debt sustainability by the IMF methodology for developing countries, in particular for Ukraine. 


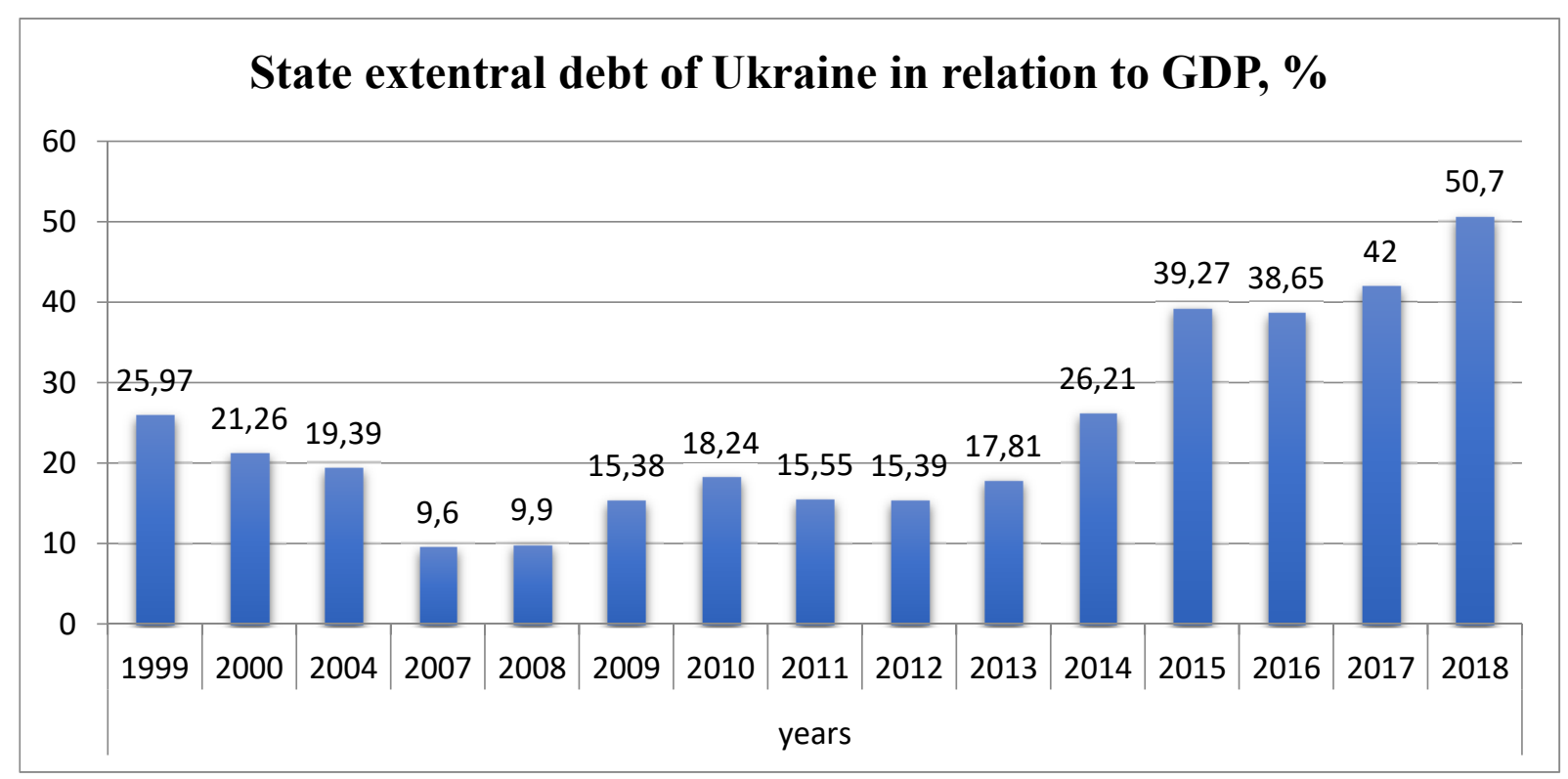

Picture 2. Dynamics of Ukraine's state external debt in relation to GDP

Source: Accounting Chamber, 2004-2018; Progress report and results of implementation of the program of activities of the Cabinet of Ministers of Ukraine, 2018; National Bank of Ukraine, 2004-2018; State Statistics Service of Ukraine, 2004-2018.)

According to L. Londar (2016), because of this trend, the government's potential increase in debt servicing is taking place, that is, a significant increase in debt pressures on the budget, while for the Ukrainian financial markets; there is an increased risk of further curtailing the currency supply and further devaluation of the hryvnia.

Despite the restructuring of debt obligations, the country's debt security remains at an extremely low, critical level. In addition, we note that some provisions of the restructuring agreement are putting some pressure on the upward trends in the Ukrainian economy. Thus, the agreement provides for an increase in the interest rate on debt obligations (from $7.22 \%$ to $7.75 \%$ ). In addition, if the growth rate of the economy exceeds $3 \%$ per year, lenders will receive $15 \%$ of the value of this percentage of GDP growth. If the economy grows more than $4 \%$ a year, lenders will receive $40 \%$ of the cost per percentage of such growth (NRA «RURIC», 2004-2017).

The above information allows us to formulate the conclusion that further growth of public debt can lead to the destruction of the state's economic independence. Excessive government debt and tight restructuring conditions exert a significant negative pressure on the financial security of the state, therefore we believe that further intensification of Ukraine's integration into the world economic and financial space should take place not through credit resources, but through investments into the country's economy with a strong national brand. An increase in the dynamics of capital inflows is a critical prerequisite for economic growth, but financial capital should enter the country mainly through direct foreign investment, and not through debt market instruments. 
According to the Ukrainian Financial Times report, corruption in Ukraine is the most important factor in curbing GDP growth, reform, and intensification of investment inflows. At the same time, the importance of the corruption factor in Ukraine is significantly above the weight of corruption in similar countries (low middle income countries and countries of Eastern Europe). Moreover, according to panel data analysis from 1998 to 2015 in Ukraine, in contrast to the EU and Eastern European countries, there is no progress in the fight against corruption.

The IMF calculations numerically prove that a lower level of corruption can raise the level of real investment in the country. S. Volosovych, Y. Baraniuk (2018) note in particular, the growth of the ICRG index (index that is inversely proportional to the level of corruption) per unit can provide real investment growth of $4 \%$. Specialists of the IMF emphasize that the weight of the factor of corruption in the dynamics of GDP and investment growth has increased significantly in recent years, compared with the 90's of the XX century.

Similar calculations conducted by Ukrainian scholars according to A. Poruchnik, M. Simonova (2015) also confirm the existence of a dependence between the influx of foreign direct investment and the index of curbing corruption, and it has been proved that even a slight positive change in this index can lead to a significant inflow of investments into Ukraine.

We agree with the opinion presented in the paper T. Zatonatskaya (2014) that the main threats to investment security can also be attributed to: insufficient use of opportunities for Ukrainian companies to enter international capital markets; a lack of a state investment strategy that results in a lack of a sound assessment of investment risks; incompatibility of the investment of the Ukrainian economy with the needs for structural adjustment; limited access to financial resources and the lack of effective mechanisms for transforming the savings of the population into investment; monopolization of foreign capital of strategic sectors of the economy of Ukraine through the privatization of strategic enterprises; regional and sectoral imbalances in investment income.

The development of a state investment policy, that should promote the development of a national brand of a competitive country, need to take into account current and long-term trends in the development of the economy. So, according to scientists Y. Harazishvili, E. Drony (2014), during the next decade, the focus will be on continuing to exhaust the competitive advantages of Ukraine in traditional export markets - cereals, metallurgy and chemical industry. This will require investment in upgrading the main technological processes of traditional industries. In general, the above-mentioned factors allow to predict the high dynamics of investment and the gradual increase of the share of accumulation of fixed capital in GDP of the country.

An equally important deterrent to Ukraine's investment and financial security is the state of the banking system, which is designed to provide economic development with financial resources. The priority of NBU activity should be a price stability, as a 
key factor in increasing the investment and financial security of Ukraine. The proper development of the banking system, integrated into the global financial system, functionally and technologically adapted to its requirements, is a prerequisite for increasing the competitiveness and security of the domestic financial sector. If by 2013 the banking system was one of the most investment-attractive branches, where a significant number of $\mathrm{M} \& \mathrm{~A}$ deals were concluded, including with the attraction of foreign capital, the last 5 years is experiencing a period of post-crisis change and recovery.

The banking sector reforms, which begun in 2014, have had a positive impact on the quality of assets and liabilities of banks (although by the end of 2017 the volume of negatively classified banking assets was still 46\%), the quality of risk assessment, the quality and legitimacy of transactions. During 2014-2017, 88 banks were considered insolvent, which adversely affected the financial security of the country. Due to the large-scale optimization of the number of banks in 4 years, total assets and liabilities were reduced three times by an estimate in USD. The capital of the banking system declined almost twofold, private individuals account for more than $70 \%$. Such a reduction in the resource base indicates a lack of credit potential to finance the real sector of the economy and the development of priority sectors with high added value, and the growth of competitive exports. The negative tendency for banks to meet the financial needs of business and the population is confirmed by the significant lag in the number of banking institutions (10 times) in Ukraine compared to the US and European countries, as well as the dynamics of resources of the banking system of Ukraine.

Extremely modest are the magnitude of the equity capital of Ukrainian banks 137.9 billion UAH on 01.01. 2018 comparing with 161,1 billion UAH registered capital (Table 1). This undermines the effectiveness of the reform aimed at reducing the number of banking institutions, as in developed countries, the accession of insolvent banks to the ability to operate, while preserving the resource base, is encouraged. At the same time, it opens the prospect of implementing technological advancements and competitive leadership.

According to statistics, as of January 1, 2018, the share of banks with foreign capital in the banking system of Ukraine was $30,70 \%$ (Table 1).

Table 1

\section{Foreign bank groups in Ukraine}

\begin{tabular}{|l|l|c|c|}
\hline \multirow{2}{*}{ Name of the bank } & \multicolumn{1}{c|}{ Country of origin } & \multicolumn{2}{c|}{ Capital investment } \\
\cline { 3 - 4 } & & UAH million & $\begin{array}{c}\text { share in the banking } \\
\text { system of Ukraine, } \%\end{array}$ \\
\hline PJSC «Prominvestbank» & Russian Federation & 40615448 & 8,199 \\
\hline PJSC «VTB BANK» & Russian Federation & 34215784 & 6,907 \\
\hline PJSC «Ukrsotsbank» & Austria & 16673140 & 3,366 \\
\hline PJSC «Sberbank» & Russian Federation & 12465461 & 2,516 \\
\hline
\end{tabular}




\begin{tabular}{|c|c|c|c|}
\hline \multirow[b]{2}{*}{ Name of the bank } & \multirow[b]{2}{*}{ Country of origin } & \multicolumn{2}{|c|}{ Capital investment } \\
\hline & & UAH million & $\begin{array}{l}\text { share in the banking } \\
\text { system of Ukraine, \% }\end{array}$ \\
\hline PJSC «Alfa-Bank» & Luxembourg & 7515616 & 1,517 \\
\hline JSC OTP Bank & Hungary & 6186023 & 1,249 \\
\hline Raiffeisen Bank Aval & Austria & 6154516 & 1,242 \\
\hline JSC «UkrSibbank» & France & 5069262 & 1,023 \\
\hline JSC «BM Bank» & Russian Federation & 3281397 & 0,662 \\
\hline PJSC «Universal Bank» & Greece & 3102672 & 0,626 \\
\hline JSC Piraeus Bank ICB & Greece & 2531347 & 0,511 \\
\hline PJSC Kredobank & Poland & 2248969 & 0,454 \\
\hline PJSC « Bank Credit Dnipro» & Cyprus & 1521000 & 0,307 \\
\hline PJSC « BTD Bank» & Kazakhstan & 1500000 & 0,303 \\
\hline PJSC «Credit Agricole Bank» & France & 1222929 & 0,247 \\
\hline PJSC CB «Pravex-Bank» & Italy & 1038007 & 0,210 \\
\hline JSC «ProCredit Bank» & Germany & 836708 & 0,169 \\
\hline PJSC «ING Bank Ukraine» & Netherlands & 731298 & 0,148 \\
\hline JSCB «Industrialbank» & Israel & 607798 & 0,123 \\
\hline PJSC «Megabank» & $\begin{array}{l}\text { Germany, United Kingdom, } \\
\text { USA }\end{array}$ & 620000 & 0,125 \\
\hline PJSC «VES Bank» & Russian Federation & 420000 & 0,085 \\
\hline PJSC Marfin Bank & Cyprus & 462101 & 0,093 \\
\hline JSC «Taskombank» & Cyprus & 308000 & 0,062 \\
\hline PJSC «Idea Bank» & Poland & 298742 & 0,060 \\
\hline PJSC «Bank Forward» & Russian Federation & 283000 & 0,057 \\
\hline PJSC «Credit Europe Bank» & Turkey & 252500 & 0,051 \\
\hline PJSC SEB Corporate Bank & Sweden & 250000 & 0,050 \\
\hline $\begin{array}{lll}\text { JSCB } & \text { «First } & \text { Investment } \\
\text { Bank» } & & \\
\end{array}$ & Russian Federation & 230000 & 0,046 \\
\hline PJSC Deutsche Bank DBU & Germany & 228666 & 0,046 \\
\hline PJSC «Bank Avangard» & Cyprus & 162382 & 0,033 \\
\hline PJSC «AP Bank» & Cyprus & 160000 & 0,032 \\
\hline PJSC «Creditvest Bank» & Turkey & 136470 & 0,028 \\
\hline JSC «KIB» & United Kingdom & 128621 & 0,026 \\
\hline JSC «Altbank» & Belarus & 126116 & 0,025 \\
\hline PJSC «Citybank» & USA & 120000 & 0,024 \\
\hline PJSC KB «Center» & France & 120000 & 0,024 \\
\hline PJSC « Sky Bank» & Kazakhstan & 120100 & 0,024 \\
\hline PJSC « Family Bank» & British Virgin Islands & 120000 & 0,024 \\
\hline \multicolumn{2}{|c|}{ Together banks of foreign banking groups } & 152064073 & 30,70 \\
\hline \multicolumn{2}{|c|}{ Together in the banking system of Ukraine } & 495377000 & 100 \\
\hline
\end{tabular}

Source: National Bank of Ukraine, 2018.

Among the large-scale and systemic problems of banks remaining in the market, it is also necessary to highlight the imbalance of the structure of assets and liabilities in terms of quality, currency, time series, and other significant closing of the activities of European financial groups in the Ukrainian financial market.

But the main problem of the banking system of Ukraine is the lack of capitalization, lack of own and regulatory capital due to changes in the norms of the NBU from 120 to 500 million UAH in 2018 and up to UAH 750 million in 2020. 
There are some factors that compensate ethis, such as: gradual increase in the level of capitalization of the banking system through mergers and acquisitions of banks with the encouragement of foreign capital, the activation of the NBU monetary instruments within the framework of the fiscal and discount policies, the increase of the efficiency of the depository clearing system, the establishment of more stringent requirements for early withdrawal of deposits, reduction of loan and deposit rates, promotion of lending to small and medium-sized businesses, development of the special methods of financial monitoring of banks, the disclosure of information about owners, etc. This will increase the competitiveness of the Ukrainian banking system at national, regional and world level, as well as create equal conditions for lending and servicing domestic and foreign business.

As a result of reforms, the state of the banking system has become less critical as the state of the Ukrainian stock market, which should be a source of credit and entrepreneurial capital. Its volumes during 2014-2017 have fallen by $70 \%$, and by 2018 , the market situation can be characterized as a long recession. Almost no primary public issues of shares of companies on domestic and foreign exchanges, sales volumes grew only in 2017. This makes it impossible to manage financial and investment resources efficiently, based on national economic potential and resulting in dependence on foreign entities and the global stock market infrastructure.

The imperfect system of regulation of financial markets in general does not contribute to the improvement of financial security. Therefore, one of the possible steps is to develop the national brand of Ukraine as a reliable partner, an investmentattractive economy through the optimization of the institutional structure of state regulation of banking and non-bank financial institutions and markets. The result will be the consolidation of domestic stock market institutions, the formation of a single central securities depository, the strengthening of information provision of foreign investors regarding the possibilities of the national stock market and the formation of its positive image, increasing the requirements for corporate governance and adapting to the standards and principles of corporate governance of the EU.

Conclusion. The national brand of competitiveness in the global economy is closely linked to the financial security factors that affect the external and internal economic environment. The level of public debt was attributed to a key factor in financial security affecting the external economic environment. Exceeding the critical threshold of public debt relation to GDP impedes the development of the real economy and creates a negative investment climate for non-financial corporations.

GDP growth caused by the favorable situation in foreign commodity markets and the speculative profit of financial corporations will not contribute to the development of the country's competitiveness in the long perspective. The low level of the banking system capitalization together with the low level of lending to the real sector deprives the real sector of using credit instruments to accelerate growth. In addition, the slow decline in our country's high level of debt dependence also diverts 
money from the real sector and, as a consequence, adversely affects the formation of a national competitive brand.

Therefore, we believe that incorporating the financial security factor into the formation of a national competitiveness brand should help to strike the right balance of economic development between the financial and real sectors.

\section{REFERENCES}

1. Alhont S. (2007). Create a State's Brand. Journal of Brand Management. Vol.1, P. 36-44.

2. Baranovsky I. (2004). Finansova bezpeka v Ukrayini (metodologiya ocinki ta mehanizmi zabezpechennya) [Financial security in Ukraine (methodology and mechanisms providing)]. Kiyivskij nacionalnij torgovelno-ekonomichnij universitet Kyiv National University of Trade and Economics. [in Ukrainian].

3. Harazishvili Y., Drony E. (2014). Prognozuvannya indikatoriv, porogovih znachen ta rivnya ekonomichnoyi bezpeki Ukrayini u serednostrokovij perspektivi [Prognozvannya indicator, porogovih znachhen ta rivnya ekonomichnoyi bezpeki Ukrayini in the mid-term perspective] Retrieved from http://www.me.gov.ua [in Ukrainian].

4. Ivashko O. (2015). Finansova bezpeka Ukrayini v umovah krizovih yavish v ekonomici [The financial security of Ukraine in conditions of the crisis phenomena in the economy]. Ekonomichnij chasopis Shidnoyevropejskogo nacionalnogo universitetu imeni Lesi Ukrayinki. Rozdil V. Groshi, finansi ta kredit. - Economic annals of the Eastern National University named Lesya Ukrainka. Section V. Money, finance and credit. Vol. 2. P. 61-66. [in Ukrainian].

5. Lanovska H. Integral assessment of business environment security / G. Blakyta, O. Matusova, H. Lanovska, V. Adamenko // Problems and Perspectives in Management. 2017. № 4. Vol. 15. P. 280-292.

6. Lekar S. (2014). Finansova bezpeka Ukrayini yak pidgruntya nacionalnoyi bezpeki derzhavi [Financial security as the basis of national safety of the State]. Aktualni pitannya finansovoyi bezpeki derzhavi. Harkivskij nacionalnij universitet vnutrishnih sprav - Topical issues of financial security of the state. Kharkiv National University of Internal Affairs. [in Ukrainian].

7. Londar I. (2016). Vdoskonalennya borgovoyi politiki yak chinnik pidvishennya rivnya finansovoyi bezpeki derzhavi [Improvement of debt policy as a factor enhancing the financial security of the State]. Ctrategichni prioriteti - Strategic priorities. Vol. 3 (40), p. 244-250.

8. Piankova O. (2014). Food and Beverage Brand Development: Global Trends and Directions for Ukraine.Journal of Economics \& Sociology. Vol. 7, No 2, P. 149-159. 
9. Pidhovniy O., Biletskaya O., Shevtsova I. (2008). Chinniki finansovoyi bezpeki Ukrayini $\mathrm{v}$ umovah globalizaciyi [Factors financial security of Ukraine in conditions of globalization]. Visnik Lvivskogo universitetu. Seriya «Ekonomichna»Bulletin of the University of Lviv. Economy Series. Vol. 39. P. 424-426. [in Ukrainian].

10. Poruchnik A., Simonova M. (2015). Institualizaciya mizhnarodnogo investuvannya $\mathrm{v}$ umovah globalizaciyi [Instalisation of international investment in conditions of globalization]. Kiyivskij nacionalnij ekonomichnij universitet - Kyiv National University of Economics. [in Ukrainian].

11. Poruchnyk A. (2008). Nacionalnij interes Ukrayini: ekonomichna samodostatnist u globalnomu vimiri [National interest of Ukraine: economic selfsufficiency in a global setting]. Kiyivskij nacionalnij ekonomichnij universitet - Kyiv National University of Economics. [in Ukrainian].

12. Subbotovich Y., Antropova O. (2013). Indikatori finansovoyi bezpeki Ukrayini [Indicators of financial security of Ukraine]. Svit finansiv - The world of finance. Vol. 2. P. 144-151. [in Ukrainian].

13. The National Institute for Strategic Studies (2018). Shlyahi virishennya problem, pov'yazanih z visokim rivnem prisutnosti inozemnogo kapitalu v bankivskij sistemi Ukrayini [Ways of solving problems connected with high level of presence of foreign capital in the banking system of Ukraine]. Retrieved from http://www.niss.gov.ua/articles/2483/ [in Ukrainian].

14. Volosovych S., Baraniuk Y. (2018). Podatkovij kontrol za operaciyami z kriptovalyutoyu v Ukrayini [Tax control of cryptocurrency transactions in Ukraine]. Banki i bankivski sistemi - Banks and Bank Systems. Vol. 13(2). P. 89-106. [in Ukrainian].

15. Zatonacka T. (2014). Investicijna bezpeka Ukrayini $\mathrm{v}$ period yevrointegracijnih procesiv [Investment security of Ukraine during the period of European integration processes]. Retrieved from http://n-auditor.com.ua/uk/ component / na _ archive /1076? view = material [in Ukrainian]. 